\title{
A PROBABLE CASE OF PASSIVE ANTING BY AN EASTERN COTTONTAIL
}

\section{RUDOLF F. KOES, Rossmere Crescent, Winnipeg, MB. R2K 0G1}

Anting is a rather frequently observed behaviour in birds. It can take two forms, active and passive. In active anting, birds rub ants or a variety of objects through their plumage. Passive anting involves a bird disturbing an ant nest and subsequently letting ants crawl over its plumage. Presumably, this behaviour provides some kind of pleasurable experience for the bird,and may have some biological benefit. ${ }^{1,3}$

Anting in mammals has rarely been reported. Hauser ${ }^{2}$ described numerous observations of young Gray Squirrels displacing birds from dust-bathing or anting locations in her North Carolina yard. The squirrels proceeded to dig and roll around in the areas, followed by wild tumbling, biting, sprawling, and more of the same. Chisholm ${ }^{1}$ reported house cats rubbing ants into their fur or rolling in ant colony waste discarded by an entomologist. As was typical of birds, the mammals appeared to enjoy these activities.

On 12 August 1995, while my wife and I were seated in our backyard, we observed a probable case of anting by an Eastern Cottontail. Our yard, which is located in a suburban area of Winnipeg, is well treed with an extensive lawn beneath. Cottontails are resident in the area and on this afternoon our attention was drawn to a nearly full-grown one in a far corner of the yard, about $15 \mathrm{~m}$ away. The rabbit stretched itself out on its belly on a patch of bare earth, where it remained motionless for a moment. Then it vigorously rolled around several times, stretched again and scratched itself, jumped up and dashed to a small spruce nearby. Beneath the spruce it 'repeated the procedure, after which it hopped out of the yard. Although the whole episode lasted probably no more than half a minute, we were both struck by the intensity of the comical actions.

Upon investigating the bare patch, which I knew was the site of an ant colony, I noted increased activity, with numerous ants scurrying around. The area under the spruce had no ants; it may have been simply a spot for the rabbit to linger and enjoy the aftereffects of its actions.

No further observations were made during the remainder of the summer and fall, but the behaviour was so similar to that described for squirrels by Hauser, ${ }^{2}$ that I have little doubt the rabbit was anting.

Acknowledgements I would like to thank Robert Nero for encouraging me to write this note, for providing reference material, and for his helpful comments on a draft of the manuscript.

1. DENNIS, J.V. 1981. Beyond the bird feeder. A.A. Knopf, Inc., New York. $201 \mathrm{pp}$.

2. HAUSER, D.C. 1964. Anting by Gray Squirrels. Jour. of Mammol. 45:136138.

3. NERO, R.W. Common Grackles anting with "Weed and Feed" lawn chemicals. Blue Jay 54(1): 31-34 